\title{
INCLUSION OF PEAS AS PROTEIN SOURCES IN THE DIET OF DAIRY GOATS IN ORGANIC BREEDING
}

\author{
Zvonko Antunović, Josip Novoselec, Željka Klir, Mislav Đidara \\ Faculty of Agriculture in Osijek, Department of Animal Science, \\ P. Svačića 1 d, 31000 Osijek, Croatia \\ zantunovic@pfos.hr
}

\begin{abstract}
The aim of this paper is to explore the possibility of inclusion grain of peas (Pisum sativum spp sativum) in the rations of lactating dairy goats in organic breeding. The research was conducted with 14 goats, French Alpine breed. Goats were in the third lactation, average age 4 years and with regard to feeding divided into two groups. The control group of goats (C) was fed with a mixture of concentrated feed $(800 \mathrm{~g} /$ day) and alfalfa hay ad libitum, while in the experimental group (E) peas (15\% in the mixture) was included in exchange for corn. Weighing and taking the body measurements as well as control milking and sampling of goats milk were conducted at the beginning and end of the research (from 70 to 100 lactation days). In goat milk content of fat, proteins, lactose, dry matter and urea as well as the number of somatic cells and microorganisms were determined. Inclusion of peas in the food of the E group of goats led to a positive impact on the indices of physical development and exterior characteristics as well as achieved greater body mass and smaller losses in the body weight during lactation, but differences between groups were not significant. In the $\mathrm{E}$ group compared to the $\mathrm{C}$ group of goats higher amount of milk was found but without significant difference, while milk urea concentration was significantly higher, which was to be expected due to better feed rations. With regard to the achieved better production effects in goats fed with the addition of peas ( $15 \%$ in food), we suggest inclusion as a protein source in food of goats in lactation from organic breeding.
\end{abstract}

Key words: peas; goats; organic breeding; production

\section{ВКЛУЧУВАЊЕ НА ГРАШОКОТ КАКО ИЗВОР НА ПРОТЕИНИ ВО ИСХРАНАТА НА МЛЕЧНИ КОЗИ ОДГЛЕДУВАНИ НА ОРГАНСКИ НАЧИН}

Целта на овој труд беше да се испита можноста за вклучување на грашокот во зрна (Pisum sativum spp sativum) во дажбите на кози во лактација, одгледувани на органски начин. Истражувањето беше изведено врз 14 кози од расата француска алпина. Козите беа во трета лактација, приближно на возраст од 4 години, поделени во две групи според исхраната. Контролната група кози (К) беше хранета со смеса од концентрирана храна (800 g/ден) и сено од луцерка ad libitum, додека за експерименталната група (Е) беше додаден грашок (15\% во смесата) во замена за пченка. Мерењето на тежината и телесните димензии, како и контролата на млечноста и земањето примероци од млекото се изведени на почетокот и на крајот на истражувањето (од 70 до 1000 лактациски дена). Во козјото млеко беше испитана содржината на масти, протеини, лактоза, сува материја и уреа, како и бројот на соматски клетки и микроорганизми. Вклучувањето на грашок во храната на групата Е на кози доведе до позитивно влијание на физичкиот развој и екстериерните карактеристики, како и до постигнување подобра жива маса и помала загуба во живата маса за време на лактацијата, но разликата помеѓу групите не беше сигнификантна. Кај козите во групата Е, во споредба со групата К, беше забележано повисоко количество на млеко, но без сигнификантна разлика, додека концентрацијата на уреа во млекото беше сигнификантно повисока, што беше и очекувано поради подобрите дажби. Поради постигнатите подобри производни ефекти кај козите хранети со додавање грашок (15\%) во храната) ние го препорачуваме неговото вклучување како извор на протеини во храната на козите во лактација одгледувани на органски начин.

Клучни зборови: грашок; кози; органско одгледување; производство

\section{INTRODUCTION}

Field peas (Pisum sativum ssp. Sativum) are a high protein feedstuff that is used as grain for ani- mal feed. Its use in feeding domestic animals is usually as an alternative to other protein feedstuffs and it is justified because of its high protein content $(22-34 \%)$. Majority of peas protein consist 
globulins and albumin (70-95\%) and as forage it has a good balance of essential amino acids. Peas, in addition to protein, is a good source of starch and besides protein it seems to be of very high quality and an economical source of protein and energy in the diets of animals [1]. Cultivation of peas for organic production is very important because with nodule bacteria it enriches soil with significant amounts of fixed nitrogen from the atmosphere that results in green fertilization [2]. In addition, its use in animal feeding of organic breeding to satisfy the needs for protein has a greater importance [3]. Soybean and its by-products are main source of animal protein in the diet, but in recent years it is excluded from the diets of animals from organic breeding because it is more polluted with genetically modified organisms [4] that are in organic production strictly prohibited. Nowadays field pea cultivars are very low in antinutritive substances and it is possible to use them as a grain without harmful effects on productivity and health of animals [5, 6]. A small number of studies on the use of peas in the feeding of small ruminants are carried out $[7,8,9]$ and are mostly aimed on the use of peas as a substitute for soybean. In combination with cereals peas is commonly used with barley because it has a rapid rate of degradation of starch which can be balanced with slight degradation of starch from peas [5]. Due to lower levels of sulfur amino acids, but also significant lysine content, the pea grain is quality upgrade of diet based on cereals [10].

The aim of the present study is to explore the possibility of inclusion of peas in the diet of lactating goats from organic breeding.

\section{MATERIALS AND METHODS}

The study was carried out with 14 goats, French Alpine breed, during the winter season of feeding, on an organic family farm. Goats were in $3^{\text {rd }}$ lactation, average age 4 years, healthy and in good condition. Goats were, due to feeding, divided into two groups. The first group of goats (control) was fed with mixture of concentrates (50\% barley, $30 \%$ corn, $10 \%$ wheat and $10 \%$ sunflower meal, $13.90 \%$ crude protein and $7.28 \mathrm{MJ}$ $\mathrm{NEL} / \mathrm{kg}$ ) in the quantity of $800 \mathrm{~g} /$ day $/$ goat and alfalfa hay ad libitum $(16.50 \%$ crude protein and 4.14 MJ NEL/kg). In the same grain mixture of the experimental group, at the expense of corn, field peas was included $(120 \mathrm{~g} /$ day/goat, or $15 \%$ of the mixture) and alfalfa hay ad libitum. In litter, goats had 1.5 goat kids in average, who were suckling until the age of 65 days. Rearing and feeding of goats was in accordance with the Regulations of organic livestock production [11]. Goats were weighed at the beginning ( 70 days of lactation \pm 5 days) and at the end of the study (100 days of lactation \pm 5 days). At the same time the body measures of goats were taken. Body condition score was assessed according to Santucci and Maestrini [12] with grades from 1 to 5 , while the indices of anamorphosis and body proportions were calculated according to Chiofalo et al. [13]. Milk yield was measured at evening and morning milking. After that, determination of fat, proteins, lactosis and dry matter of milk were done by the infrared spectrometric method (HRN ISO 9622:2001). The total number of somatic cells (SS) in milk was determined by the fluoro opto electronic method (HRN EN ISO 13366-2:2007). Microbiological analysis of milk was done by the flow cytometry epifluorescent method (IDF 161A: 1995). Urea milk content was done by the color spectrophotometric method. The amount of milk produced per goat was determined on the basis of the milk volume in milliliters and its recalculation of the mass by using a conversing factor, which is 1.030 for goats [14]. The research results were analyzed by the LSD-test in the computer program [15] and expressed as arithmetic mean (mean) and standard deviation (sd). Significance of differences was expressed at the level $(\mathrm{P}<0.05)$.

\section{RESULTS AND DISCUSSION}

Table 1 presents the exterior characteristics and indices of goats' development in organic breeding fed with the addition of peas.

The inclusion of peas in the diet of goats from the experimental group had positive influence on the indices of physical development and exterior characteristics and achieved greater weight and less weight losses of goats during lactation (Table 2), but differences between groups were not significant. Addition of cereals in diets often gives lower body weight gain than those fed with the addition of legumes grain-peas $[16,17]$. The replacement of cereal grain by legumes, in general, raises consumption and feed conversion, weight gain and wool growth, which explains their high proportion of metabolic energy and nitrogen content [18]. Achieved losses in body weight of 
lactating goats are in accordance with the previous research and knowledge about the metabolism in lactating goats [19]. Morand-Fehr et al. [20] and Badamana et al. [21] concluded that the goats per kidding in the first month of lactation lose $1 \mathrm{~kg}$ of the body weight per week, and in the next month, $0.5 \mathrm{~kg} /$ week. Body weight losses of goats from the control group were in agreement with these studies. However, the experimental group of goats had less weight losses, which are probably the reason of the higher quality diet and the later stage of lactation. Hadjipanayiotou [22] found that goats in the middle of lactation which produce $2.5 \mathrm{~kg}$ of milk, corrected on milk fat, require diets that con- sist $16 \%$ of crude protein. Most of these authors concluded that the mobilization of body reserves of fat and protein occurs in the early stages of lactation in goats, which even do not have to be closely associated with changes in the body weight. Lanza et al. [23] presented that crude proteins from peas, as in other legume seeds, have a low level of avoiding ruminal degradation and high digestibility, which could be a disadvantage in providing of proteins in diets of high dairy goats. Loe et al. [24] pointed out that the qualitative substitute of corn with peas is possible in feeding lambs at the rate of $450 \mathrm{~g} / \mathrm{kg} \mathrm{DM}$.

Table 1

Exterior characteristics and development indices of goats in organic farming

\begin{tabular}{lccc}
\hline \hline Indicators & \multicolumn{2}{c}{$\begin{array}{c}\text { Groups (mean } \pm \text { sd) } \\
\text { Control }\end{array}$} & $\begin{array}{c}\text { Experiment } \\
\text { Significance } \\
\text { (P value) }\end{array}$ \\
\hline Withers height, cm & $67.43 \pm 1.92$ & $68.93 \pm 3.25$ & 0.443 \\
Carcass length, cm & $64.71 \pm 4.11$ & $69.79 \pm 5.57$ & 0.131 \\
Chest circumference, cm & $85.14 \pm 6.30$ & $85.43 \pm 5.87$ & 0.859 \\
Chest width, cm & $14.07 \pm 5.89$ & $15.86 \pm 1.57$ & 0.490 \\
Shin-bone circumference, cm & $8.40 \pm 0.38$ & $8.14 \pm 0.27$ & 0.197 \\
Body condition score & $3.00 \pm 0.50$ & $3.24 \pm 0.24$ & 0.561 \\
Anamorphosus index & $107.96 \pm 15.17$ & $107.75 \pm 15.89$ & 0.985 \\
Body proportion index & $66.23 \pm 7.08$ & $66.83 \pm 11.58$ & 0.883 \\
\hline \hline
\end{tabular}

Table 2

Body weight and gains of goats during the research

\begin{tabular}{lccc}
\hline \hline \multirow{2}{*}{ Indicator } & \multicolumn{2}{c}{ Groups (mean $\pm \mathrm{sd}$ ) } & Significance \\
& Control & Experiment & (P value) \\
\hline Initial body weight, $\mathrm{kg}$ & $46.39 \pm 5.60$ & $47.16 \pm 8.20$ & 0.764 \\
Final body weight, $\mathrm{kg}$ & $44.69 \pm 5.29$ & $46.29 \pm 9.34$ & 0.619 \\
Total gain, kg/animal & $-1.70 \pm 1.86$ & $-0.87 \pm 2.17$ & 0.448 \\
Gain, g/day & $-56.67 \pm 62.09$ & $-29.05 \pm 72.41$ & 0.448 \\
\hline \hline
\end{tabular}

Analyzing the Table 3 it is evident that the higher amount of milk was determined, but with no significant difference $(\mathrm{P}<0.05)$, while the urea content in milk of goats fed with the addition of peas compared to those fed with cereal grains was significantly higher $(\mathrm{P}<0.01)$, which was expected because of the better diet. Other parameters of the chemical composition of milk, as well as somatic cells and microorganisms were not different.

In Australia with inclusion of $3.5 \mathrm{~kg} /$ day ground pea replacing the barley grain in lowproducing dairy cows, an increased milk yield by $0.9 \mathrm{~kg} /$ day was found [25]. In most studies conducted by replacing corn with soybeans or peas in the diets of ruminants had no effect on milk pro- 
duction [26, 27, 28, 29] but the chemical composition of milk in a smaller number of studies in terms of fat and urea differed. The study by Liponi et al. [30] using peas in feed of lactating ewes showed a similar chemical composition of milk, but lower protein content compared to the sheep fed with added soybean meal or bean fodder.

Table 3

The amount and chemical composition of goat milk

\begin{tabular}{lccc}
\hline \hline \multirow{2}{*}{ Indicators } & \multicolumn{2}{c}{ Groups (mean \pm sd) } & $\begin{array}{c}\text { Significance } \\
\text { (P value) }\end{array}$ \\
\hline Milk amount, kg/day & Control & Experiment & 0.165 \\
Dry matter, \% & $1.99 \pm 0.59$ & $2.21 \pm 0.44$ & 0.374 \\
Protein, \% & $11.72 \pm 0.60$ & $11.32 \pm 0.93$ & 0.988 \\
Fat, \% & $2.75 \pm 0.29$ & $2.76 \pm 0.33$ & 0.447 \\
Lactosis, \% & $3.58 \pm 0.42$ & $3.36 \pm 0.63$ & 0.094 \\
Dry matter without fat, \% & $4.38 \pm 0.19$ & $4.21 \pm 0.13$ & 0.577 \\
Urea, mg/dl & $8.14 \pm 0.44$ & $7.96 \pm 0.43$ & 0.001 \\
Number of somatic cells, SC/ml & $17.36 \pm 2.97$ & $32.14 \pm 5.95$ & 0.881 \\
Number of microorganisms, cfu/ml & $6857.14 \pm 6414.27$ & $6142.86 \pm 2544.84$ & 0.801 \\
\hline \hline
\end{tabular}

In the study by Volpelli et al. [28] a significant increase in urea was found in the milk of cows fed peas in groups which may lead to better degradability of extruded peas protein fractions. Bonomi et al. [9] when feeding lactating goats with addition of 5 and $10 \%$ of pea meal in partial substitution of soybean meal and maize meal, found that it does not affect the milk production and health status of goats.

According to Renna et al. [8] peas can be effectively used as a source of protein in exchange for soybeans in low or high productive dairy sheep. The authors found no significant differences in the quantity and chemical composition of sheep milk, neither in the number of somatic cells and bacteria in milk. Antunovic et al. [31] found similar amounts and chemical composition of goat milk from organic breeding.

\section{CONCLUSION}

With regard to determined little bit better production performance of lactating dairy goats from organic production fed with diets supplemented with $15 \%$ of peas, its inclusion in diets is justified.

\section{REFERENCES}

[1] Jezeierny, D., Mosenthin R., Bauer E. (2010): The use grain legumes as a protein source in pig nutrition: A review. Anim. Feed Sci. Tech, 157, 111-128.

[2] Ćupina, B., Mihailović, V., Erić P., Mikić, A. (2005): Proteinski grašak - činilac racionalne proizvodnje stočne hrane. Zbornik radova. Naučni Institut za ratarstvo $i$ povrtlarstvo, 41, 171-180.

[3] Cozzi, G., Boukha, A., Contiero, B., Gottardo, F. (2010): Extruded pea (Pisum sativum) as alternative to soybean protein for dairy cows feeding in organic Alpine farms. Ital. J. Anim. Sci., 9, 194-199.

[4] Hewlett, K. L., Azeez, G. S. E. (2008): The economic impact of GM contamination incidentes on the organic sector. Proceedings of the 16th IFOAM Organic World Congress „Cultivate the Future“, Modena, Italy, June 18-20, 2008. http://orgprints.org/view/projects/conference.html.

[5] Corbett, R. R. (1997): Peas as a protein and energy source for ruminants. Advances in Dairy Technology, 9, 213247.

[6] Castell, A. G., Guenter, W., Igbasan, F. A. (1996): Nutritive value of peas for nonruminant diets. Animal Feed Sci. Technology, 60, 209-227.

[7] Tufarelli, V., Naz, S., Khan, R. U., Mazzei, Laudadio, D. (2012): Milk quality, manufacturing properties and blood biochemical profile from dairy cows fed peas (Pisum sativum L.) as dietary protein supplement. Arch Tierz, 55, 132-139. 
[8] Renna, M., Cornale, P., Lussiana, C., Malafatto, V., Forina, R., Mimosi, A., Battaglini, L. M. (2012): Use of Pisum sativum (L.) as alternative protein resource in diets for dairy sheep: Effect on milk yield, gross composition and fatty acid profile. Small Ruminant Research, 102, 142-150.

[9] Bonomi, A., Bonomi, B. M., Mazzotti A., Vonghia G., Caputi Jambrenghi, A. (2003): The use of pea meal (Pisum sativum L.) in dairy goat feeding. Rivista di Scienza dell'Alimentazione, 32 (3), 293-301.

[10] Mc Phee, K. (2003): Dry pea production and breeding A mini-review. Food, Agriculture \& Environment, 1, 1, 64-69.

[11] Pravilnik o ekološkoj proizvodnji životinjskih proizvoda, N.N. 13/02.

[12] Santucci, P. M., Maestrini O. (1985): Body condition of dairy goats in extensive systems of production: method of estimation. Ann. Zootech, 34, 471-490.

[13] Chiofalo, V., Liotta, L., Chiofalo, B. (2004): Effects of the administration of Lactobacilli on body growth and on the metabolic profile in growing Maltese goats kids. Reprod. Nutr. Dev., 44, 449-457.

[14] ICAR International Regulation for milk recording in sheep. Institute de l'Elevage, Paris, 15 pp (1992).

[15] Statistica-Stat Soft, Inc. version 8.0, 2008, www.statsoft.com

[16] Hodge, R. W., Bogdanovic, B. (1983): Feeding hay supplemented with peas or low protein oats to crossbred lambs born in the spring. Australian Journal of Experimental Agriculture and Animal Husbandry, 23, 19-23.

[17] Morcombe, P. W., Ferguson, J. (1990): Lupin, pea and wheat grain as supplements for young Merino, sheep grazing wheat stubble. Proceedings of the Australian Society of Animal Production, 18, 304-307.

[18] Dixon, R. M., Hosking, B. J. (1992): Nutritional value of grain legumes for ruminants. Nutrition Research Reviews, 5, 19-43.

[19] AFRC Technical Committee on Responses to Nutrients: The nutrition of goats. Cab International, UK (1998).

[20] Morand-Fehr, P., Sauvant, D., Brun-Bellut, J. (1987): Recommendations alimentaires pour les caprins. Bulletin Technique, C.R.Z.V. Theix 70, 213-222.
[21] Badamana, M. S., Sutton, J. D., Oldham, J. D., Mowlem, A. (1990): The effect of amount of protein in the concentrates on hay intake and rate of passage, diet digestibility and milk production in British Saanen goats. Animal Production, 51, 333-342.

[22] Hadjipanayiotou, M. (1986): Studies on the response of lactating Damascus goats to dietary protein. J. Anim. Physiol. Anim. Nutr, 57, 41-52.

[23] Lanza, M., Bella, M., Priolo A., Fasone V. (2003): Peas (Pisum sativum L.) as an alternative protein source in lamb diets: growth performances, and carcass and meat quality. Small Rum. Res., 47, 63-68.

[24] Loe, E. R., Bauer, M. L., Lardy, G. P., Caton, J. S., Berg, P. T. (2004): Field pea (Pisum sativum) inclusion in cornbased lamb finishing diets. Small Rum. Res, 53, 39-45.

[25] Valentine, S. C., Bartsch, B. D. (1990): Milk production by dairy cows fed legume grain with or without urea as supplements to cereal hay based diet. Australian Journal of Experimental Agriculture, 30, 1, 7-10.

[26] Vander Pol, M., Hristov, A. N., Zaman, S., Delano, N., Schneider, C. (2009a): Effect of inclusion of peas in dairy cow diets on ruminal fermentation, digestibility, and nitrogen losses. Animal Feed Science and Technology, 150, 95-105.

[27] Vander Pol, M., Hristov, A. N., Zaman, S., Delano N. (2009b), Peas can replace soybean meal and corn grain in dairy cow diets. J. Dairy Sc., 91, 698-703.

[28] Volpelli, L. A., Comeleini, M., Masoero, F., Moschini, M., Fiego, D. P. L., Scipioni R. (2009): Pea (Pisum sativum) in dairy cow diet: effect on milk production and quality. Ital. J. Anim. Sci., 8, 245-257.

[29] Khorossani, G. R., Okine, E. K., Corbett, R. R., Kennelly, J. J. (2001): Nutritive value of peas for lactating dairy cattle. Can. J. Anim. Sci. 81, 541-551.

[30] Liponi, G. B., Casini, M., Martini, M., Gatta, D. (2007): Faba bean (Vicia faba minor) and pea seeds (Pisum sativum), a protein sources in lactatin ewes' diets. Ital. J. Anim. Sci., 6 suppl. 1, 309-311.

[31] Antunović, Z., Šperanda, M., Mioč, B., Novoselec, J., Šperanda T. (2009): Zum Ernahrungszustand von Ziegen unter organischen Produktionsbedingungen. Tierarztliche Umschau, 64 (1), 18-23. 